\title{
No effect of intramuscular gold therapy on serological parameters of Helicobacter pylori infection in patients with rheumatoid arthritis: a 12 month prospective study
}

Saskia ten Wolde, Matthijs Janssen, Wim van Duijn, Cornelis B H W Lamers, Jo Hermans, Ben A C Dijkmans

\begin{abstract}
Objectives-To assess prospectively the influence of intramuscular gold therapy on Helicobacter pylori serology in patients with rheumatoid arthritis (RA).

Methods-Fifty patients with $\mathrm{RA}$ were started on intramuscular gold or chloroquine, as the control group and were followed serologically for $H$ pylori infection for 12 months.

Results-Twelve patients treated with gold and eight control patients treated with chloroquine, all with serological evidence for $H$ pylori infection, showed no significant decline of $\operatorname{IgA}$ and IgG anti-H pylori antibody levels or serum pepsinogen $A$ and $C$ levels. Total serum IgA and IgG levels declined significantly during gold therapy, while they remained unchanged during chloroquine therapy.

Conclusions-Intramuscular gold therapy in patients with RA does not influence the serological parameters of $H$ pylori infection.
\end{abstract}

(Ann Rheum Dis 1994; 53: 400-402)

Patients with rheumatoid arthritis (RA) have an increased risk of developing peptic ulcer disease (PUD). ${ }^{1}$ Major factors in the pathogenesis of PUD in patients with RA are the chronic intake of nonsteroidal antiinflammatory drugs (NSAIDs) and the presence of Helicobacter pylori in the gastric mucosa. $^{2}$

Intramuscular gold, widely used in the treatment of patients with RA, may have an antibacterial effect on $H$ pylori, leading to a reduction of PUD. ${ }^{3}$ In vitro gold has a thirty times stronger bactericidal effect toward $H$ pylori than bismuth compounds. ${ }^{4}$ In vivo it has been observed that patients with RA with long term intramuscular gold therapy have a reduced prevalence of peptic ulceration and decreased levels of antibodies against $H$ pylori..$^{5-7}$ Based on these observations it could be suggested that intramuscular gold might influence the colonisation of the gastric mucosa by $H$ pylori.

As no prospective study had been undertaken, we investigated the course of sero- logical parameters for $H$ pylori infection in patients with RA during the first 12 months of intramuscular gold therapy.

\section{Patients and methods}

PATIENTS

We studied 30 consecutive patients with RA who started with intramuscular gold therapy (aurothioglucose) and 20 consecutive patients with RA who started with chloroquine therapy. None of the patients had been treated with triple antibacterial therapy for PUD. After informed consent was given, blood samples were obtained at the start and after 1 , 2, 3, 6, 9 and 12 months of therapy. Patients were excluded from analysis if their therapy was discontinued within the first three months.

\section{SERUM ANTI $H$ PYLORI IgA AND IgG}

Specific $\operatorname{IgA}$ and $\operatorname{IgG}$ antibodies against $H$ pylori were measured by an enzyme linked immunosorbent assay (ELISA), as described elsewhere. ${ }^{8}$ In our analysis we used the absolute values for IgA and IgG antibodies against $H$ pylori, expressed as an absorption index (AI), and the cutoff point for seropositivity to $H$ pylori (AI $>0.32$ for IgG antibodies).

\section{TOTAL IgA AND IgG}

Serum IgA and IgG levels were measured by rate nephelometry (Beckmann). ${ }^{9}$ Since it is known that during gold therapy the total serum IgA and IgG levels decline, ${ }^{10}$ we calculated the ratio of specific antibodies to $H$ pylori to total serum immunoglobulin levels.

\section{PEPSINOGEN A AND C}

Serum pepsinogen $\mathrm{A}$ and $\mathrm{C}$ concentrations were determined in patients treated with intramuscular gold by specific and sensitive radioimmunoassays, as described in detail elsewhere. ${ }^{11}$ In chronic superficial gastritis, which is caused by $H$ pylori, pepsinogen $\mathrm{A}$ and $\mathrm{C}$ levels are increased. Normalisation of pepsinogen levels can successfully predict eradication of $H$ pylori in $96 \%$ of the patients. $^{12}$ 
Serological parameters for $\mathrm{H}$ pylori infection and total serum immunoglobulins in rheumatoid arthritis patients with serological evidence for $\mathrm{H}$ pylori infection during intramuscular gold or chloroquine therapy

\begin{tabular}{|c|c|c|c|c|c|c|c|}
\hline \multirow{2}{*}{$\begin{array}{l}\text { Serological } \\
\text { parameters }\end{array}$} & \multicolumn{3}{|c|}{ Intramuscular gold $(n=12)$} & \multicolumn{3}{|c|}{ Chloroquine $(n=8)$} & \multirow{2}{*}{ 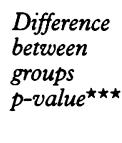 } \\
\hline & $\begin{array}{l}\text { Before } \\
\text { treatment } \\
\text { mean (SEM) }\end{array}$ & $\begin{array}{l}\text { After } 3-12 \\
\text { months treatment } \\
\text { mean (SEM) }\end{array}$ & $\begin{array}{l}\text { Change } \\
\text { per month } \star \star \\
\text { mean slope (SEM) }\end{array}$ & $\begin{array}{l}\text { Before } \\
\text { treatment } \\
\text { mean (SEM) }\end{array}$ & $\begin{array}{l}\text { After } 3-12 \\
\text { months treatment } \\
\text { mean (SEM) }\end{array}$ & $\begin{array}{l}\text { Change } \\
\text { per month }{ }^{\star \star} \\
\text { mean slope (SEM) }\end{array}$ & \\
\hline $\begin{array}{l}\text { IgA antibodies to } H \text { pylori (AI) } \\
\text { Total serum IgA (g/) } \\
\text { Ratio IgA anti-HP/total IgA }\end{array}$ & $\begin{array}{l}0 \cdot 73(0.09) \\
3 \cdot 2(0 \cdot 39) \\
0 \cdot 26(0 \cdot 05)\end{array}$ & $\begin{array}{l}0.55(0 \cdot 11) \\
2 \cdot 2(0 \cdot 26)^{\star} \\
0 \cdot 29(0.08)\end{array}$ & $\begin{array}{r}-0.025(0.024) \\
-0.194(0.075) \\
0.011(0.011)\end{array}$ & $\begin{array}{l}1 \cdot 1(0 \cdot 24) \\
3 \cdot 0(0.35) \\
0.38(0.08)\end{array}$ & $\begin{array}{l}1 \cdot 1(0 \cdot 28) \\
2 \cdot 7(0 \cdot 48) \\
0.52(0 \cdot 18)\end{array}$ & $\begin{array}{r}0.001(0.012) \\
-0.027(0.032) \\
0.014(0.014)\end{array}$ & $\begin{array}{l}0 \cdot 41 \\
0 \cdot 10 \\
0 \cdot 86\end{array}$ \\
\hline $\begin{array}{l}\text { IgG antibodies to } H \text { pylori (AI) } \\
\text { Total serum IgG }(g / l) \\
\text { Ratio IgG anti-HP/total IgG }\end{array}$ & $\begin{array}{l}0.56(0.05) \\
13 \cdot 8(0 \cdot 66) \\
0.041(0.003)\end{array}$ & $\begin{array}{c}0.52(0.05) \\
11 \cdot 4(0 \cdot 82)^{\star} \\
0.046(0.004)\end{array}$ & $\begin{array}{r}-0.001(0.036) \\
-0.442(0.167) \\
0.001(0.001)\end{array}$ & $\begin{array}{l}0.69(0.07) \\
13.0(0 \cdot 55) \\
0.054(0.005)\end{array}$ & $\begin{array}{l}0.68(0.07) \\
12 \cdot 7(0.92) \\
0.055(0.007)\end{array}$ & $\begin{array}{r}-0.002(0.003) \\
-0.030(0.084) \\
0.000(0.001)\end{array}$ & $\begin{array}{l}0.92 \\
0.07 \\
0 \cdot 19\end{array}$ \\
\hline $\begin{array}{l}\text { Serum pepsinogen } A \\
\text { Serum pepsinogen } C \\
\text { Ratio of pepsinogen } A / C\end{array}$ & $\begin{array}{l}57 \cdot 3(12 \cdot 8) \\
35 \cdot 7(7 \cdot 2) \\
1 \cdot 6\end{array}$ & $\begin{array}{l}43 \cdot 3(7 \cdot 9) \\
28 \cdot 1(5 \cdot 5) \\
1 \cdot 7(0 \cdot 19)\end{array}$ & $\begin{array}{r}-4.205(3.933) \\
-2 \cdot 155(2.139) \\
0.019(0.029)\end{array}$ & $\begin{array}{l}\text { not done } \\
\text { not done } \\
\text { not done }\end{array}$ & $\begin{array}{l}\text { not done } \\
\text { not done } \\
\text { not done }\end{array}$ & $\begin{array}{l}\text { not done } \\
\text { not done } \\
\text { not done }\end{array}$ & \\
\hline
\end{tabular}

${ }^{\star} \mathrm{p}$ value $<0.01$ (paired $t$ test within group); ${ }^{\star \star}$ mean of individual slopes (linear regression analysis per patient); ${ }^{\star \star \star} \mathrm{p}$ value $t$ test difference between groups for individual slopes.

STATISTICAL METHODS

The difference between values before and after therapy (last value) within the two treatment groups were compared using the paired $t$ test and the Wilcoxon's signed rank test. The difference between the groups of the changes during therapy of the serological results (before minus after) were compared using the $t$ test for group difference.

The course of the serological parameters during therapy were assessed by linearregression analysis over time. The difference between the groups of the individual slopes was compared using the $t$ test for groups.

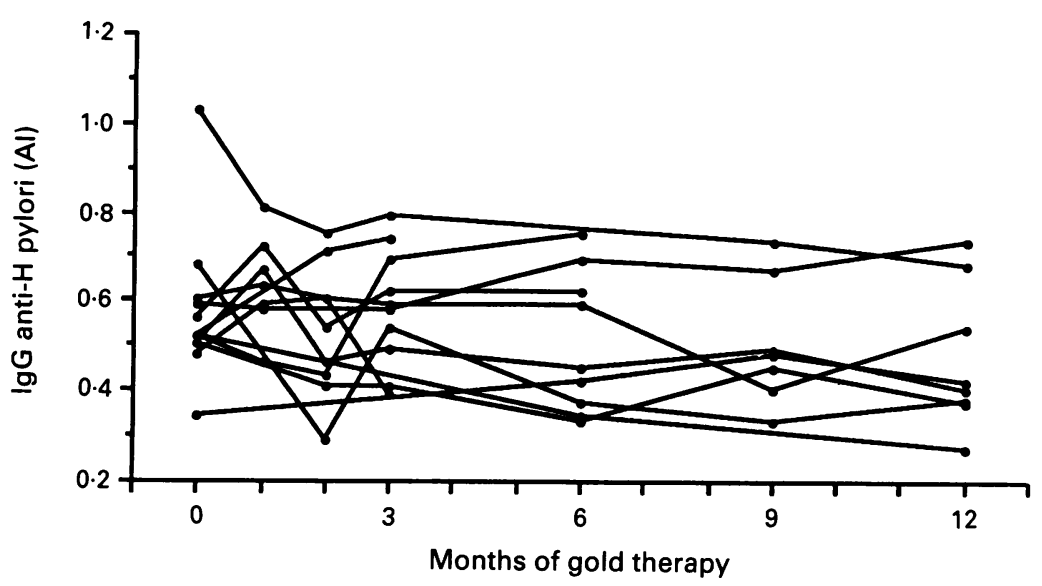

Figure 1 Individual courses during 12 months of intramuscular gold therapy of IgG antibody levels to $\mathrm{H}$ pylori in 12 patients with rheumatoid arthritis who were seropositive to $\mathrm{H}$ pylori at the start of gold therapy (absorption index (AI) $>0.32$ for IgG antibodies).

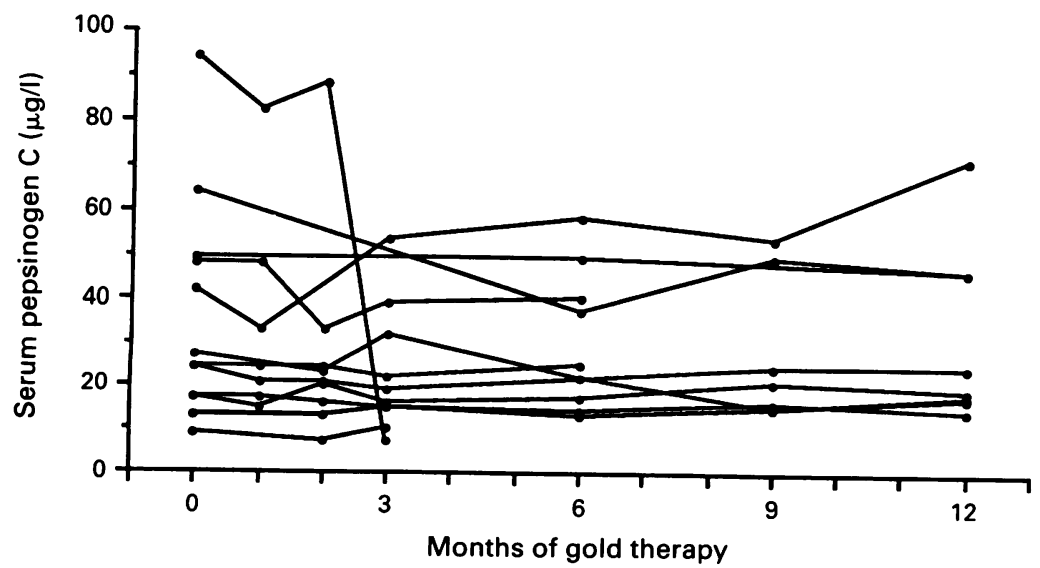

Figure 2 Individual courses during 12 months of intramuscular gold therapy of serum pepsinogen $C$ levels $(\mu g /)$ in 12 patients with rheumatoid arthritis with serological evidence for a $\mathrm{H}$ pylori infection at the start of gold therapy.

\section{Results}

Four of the 50 patients were excluded for evaluation because their therapy was discontinued within three months. The demographic and clinical data of the remaining 27 patients with gold therapy and 19 patients with chloroquine therapy were well balanced for most of the parameters (data not shown).

We analysed the subgroup of patients with serological evidence for $H$ pylori infection, which means patients with an AI greater than 0.32 for IgG anti-H pylori. Twelve (44\%) of 27 evaluable patients with RA starting with intramuscular gold and eight $(42 \%)$ of 19 evaluable patients starting with chloroquine therapy were seropositive for $H$ pylori. Therapy was discontinued between three and 12 months in four of the 12 patients in the gold group and one of the eight patients in the chloroquine group. The last available value of these patients was used for analysis.

Mean (SD) values of the serological parameters before and after three to 12 months of intramuscular gold therapy [mean $9.5(3.8)$ months] or chloroquine therapy [mean 11.6 (1.1) months] in 20 patients with serological evidence for a $H$ pylori infection are given in the table. During intramuscular gold therapy the mean total serum IgA and IgG levels declined significantly, while there was no significant decline of anti- $H$ pylor $i$ IgA and IgG antibody titres and pepsinogen $\mathrm{A}$ and $\mathrm{C}$ levels. Moreover, the ratio of $\operatorname{IgA}$ and IgG antibodies to $H$ pylori to total serum IgA respectively IgG, and the ratio of pepsinogen A to pepsinogen $\mathrm{C}$ did not change during gold therapy. There was no decreasing tendency in any of the serological parameters during chloroquine therapy and there was no significant difference between the treatment groups.

With linear regression analysis none of the patients on gold therapy showed a significant decline of IgG antibody levels against $H$ pylori (fig 1). One patient with a decline of serum pepsinogen $C$ level died six months after the last value because of a metastatic longcarcinoma (fig 2). Furthermore there was no difference in the mean slopes of $\operatorname{IgA}$ and $\operatorname{IgG}$ anti- $H$ pylori antibody levels between the gold and chloroquine group (table). 


\section{Discussion}

The main conclusion of this study is that 12 months of intramuscular gold therapy does not influence the most specific and sensitive serological markers for an $H$ pylori gastritis, namely the serum pepsinogen $\mathrm{C}$ and IgG anti-H pylori levels.

If gold therapy was equally effective against $H$ pylori as conventional antibiotic triple therapy (two week treatment with colloidal bismuth subcitrate, metronidazole and amoxicillin), eradication of the bacteria could be expected in $80-90 \%$ of our patients. Kosunen et al showed that a fall of $50 \%$ in IgG anti- $H$ pylori titre during six months indicates eradication of the $H$ pylori bacteria with a high specificity and sensitivity. ${ }^{13}$ However, none of our patients showed a $50 \%$ decrease in IgA or IgG antibodies against $H$ pylori during 12 months of therapy, by which time eradication of $H$ pylori in any of the patients becomes very unlikely.

The assumption, however, that gold as monotherapy is equally effective as triple therapy against $H$ pylori is not realistic. In vitro $H$ pylori is sensitive to a wide range of antibacterial agents, but in vivo all have failed when used as monotherapy. ${ }^{1+}$ Even bismuth subcitrate had an eradication rate of at most $30 \%$. It is conceivable that gold in the doses used for RA does not eradicate $H$ pylori, but only suppresses the bacteria. ${ }^{3}$ However, in the latter situation we should have seen a decline in the serum pepsinogen $A$ and $C$ levels as markers of chronic superficial gastritis, which we did not observe.

The earlier reported decreased levels of antibodies against $H$ pylor ${ }^{6}{ }^{-}$in patients treated with intramuscular gold might be ascribed to a non-specific overall effect of gold, resulting in a decline of serum immunoglobulins. ${ }^{11}$ While the serological tests for antibodies against $H$ pylori are probably not reliable in the surveillance of $H$ pylori during gold therapy, we determined serum pepsinogen $\mathrm{A}$ and $\mathrm{C}$ levels in these patients as well.

In conclusion, intramuscular gold does not seem to have a clinically relevant bactericidal or suppressive effect towards $H$ pylori in patients with RA in our one year study. To investigate whether gold compounds prevent the occurrence of $H$ pylori associated PUD, a prospective study should be undertaken in patients with RA who are especially at risk for PUD (history of PUD, chronic usage of NSAIDs, $H$ pylori infection). The $H$ pylori infection should be confirmed by culture, histology and urease test. Patients should be randomly assigned to three groups: a goldtreated group, those treated with other DMARDs, and a group treated with triple therapy. The eradication rate of $H$ pylori and incidence of PUD should be assessed by endoscopy. Unfortunately ethical aspects will probably not permit such a study design. So for the present, we agree with Guslandi, that it is still too early for the gold rush. ${ }^{15}$

1 Janssen . M, Dijkmans B A C, Van der Slurs F A. it al. Lpper gastrointestinal complaints and complications in chronic gastromtestinal complaints and complications in chronic rheumatic patients in comparison with
diseases. $B r \cdot 7$ Rhicumatol $1992 ; 31:-7+7-52$.

2 Shallcross T M, Rathbone B J, Wratt J I, Heatler R V. Helicobacter pylori associated chronic gastritis and peptic ulceration in patients taking nonsteroidal antiinflammatory drugs. Alimem Pharmacol Therap 1990; 4 $515-22$.

3 Taha A S, Sturrock R D. The gold plated stomach? Amak R/cutu Dis 1993; 52: 89-90)

+ Braga L L, Sarosiek J, Marshall B, McCallum R W. Barrett L, Guerrant R. Gold- a new potential drug treatment of Helicobacter pylori infection. (iastrochterology (Abs A25) 1990; 98

5 Taha A S, Capell H A, Sturrock R I), Russell R I Nonsteroidal peptic damage in rheumatoid patients receiving second-line drugs. Am f (jastrocmterd 1991; 86: $1588-91$

6 Taha A S, Sturrock R D. Russell R I. Helicobacter pylori and peptic ulcers in rheumatoid arthritis patients receiving gold, sulfasalazine, and nonsteroidal antiinflammatory drugs. Am f (iastrienterology 1992; 87: $1732-35$.

7 Janssen M. Dijkmans B A C, Vandenbroucke J P, Duijn van W, Pena A S, Lamers C B H W Decreased level of antibodies against Helicobacter pylori in patients with rheumatoid arthritis receiving intramuscular gold. Amm Rheum Dis 1992; 51: 1036-38

8 Pena A S, Endts H Ph, Offerhaus (; J A, it al. Value of serology (ELISA and immunoblotting) for the diagnosis of Campvlobacter pvlori infection. Digestion 1989; 44: $131-41$.

9 Deaton C D, Maxwell K W, Smith R S, Reveling R I.. Use of laser nephelometry in the measurement of serum proteins. Clin Chem 1976; 22: 1465-71.

10 Gottleib N L, Kiem I M, Pennevs N S, Schultz D) R. The influence of chrssotherapy on serum protein and immunoglobulin levels, rheumatoid factor, and antiepithelial antibody titers. F Lab Clin Med 1975; 86: 962-72.

11 Biemond I, Jansen J B M J, Crobach L F S J, Kreuning J, Lamers C B H W. Radioimmunoassay of human pepsinogen $\mathrm{A}$ and pepsinogen C. I C.lin (hem Clin Biochem 1989; 27: 19-25.

i 2 Veenendaal R A, Gotz. J M, Biemond I, ct al. Monitoring of treatment results by six serological markers of Helicobacter pylori. Ned $\dot{f} \mathrm{Med}$ (in press).

13 Kosunen T U, Seppela K, Sarna S, Sipponen P. Diagnostic value of decreasing $\operatorname{IgG}, \operatorname{IgA}$, and $\operatorname{IgM}$ antibody titres value of decreasing $\mathrm{IgG}, \mathrm{IgA}$, and $\mathrm{IgM}$ antibody titres after eradica

14 McKinlay A W. Antibiotics in the treatment of peptic ulcer disease. F Antimicrob Chemother 1992; 29: 92-6.

15 Guslandi M. Still too carly for the gold rush. Am Rhemm I) is $1993 ; 52: 623-4$. 